\title{
Nasal Cavity and Ethmoid Sinus Cancer Clinical Distant Metastasis TNM Finding v7
}

National Cancer Institute

\section{Source}

National Cancer Institute. Nasal Cavity and Ethmoid Sinus Cancer Clinical Distant

Metastasis TNM Finding v7. NCI Thesaurus. Code C89114.

A clinical finding about one or more characteristics of nasal cavity and ethmoid sinus cancer, following the rules of the TNM AJCC v7 classification system as they pertain to distant metastases. 